\title{
9. Art journalism and the impact of 'globalisation': New fugal modalities of storytelling in Austral-Asian writing
}

\section{ABSTRACI}

The writing of art journalism has played a key yet little acknowledged role in the ongoing expansion of the international contemporary art world, and the multi-billion dollar global art economy. This article discusses some contradictory impacts of globalisation on art journalism-from extremes of sensationalist record-breaking art market reporting in the global mass media to the emergence of innovative modalities of story-telling in Australian independent journalistic art writing. Using aspects of Bourdieu's field theory, the article discusses complexities of overlapping fields of economic and cultural production in art journalism and proposes a new modality of cultural criticism based on musical fugue form. Reflecting on two case studies - magazine feature stories on contemporary artists, Guo Jian from China, and Charlie Co from the Philippines- the article considers the attribution of value, 'the new global aesthetic', and new forms of autonomous independent art journalism as cultural production.

Keywords: art journalism, globalisation, cultural criticism, field theory

\section{RUTH SKILBECK}

University of Technology, Sydney

\section{Introduction}

7 HE WRITING of art journalism has played a key yet largely unacknowledged subliminal role in the exponential expansion of

1 the international contemporary art world and the multibillion dollar global art economy over the past two decades. Yet little research has been conductedinto the contradictions and pathologies of thisincreasinglysignificant 
mediated form of 'global' cultural and social communication. The purpose of this reflective article is to begin to think about the wider social and cultural significances of art journalism. I will do this by discussing two case studies of reflective practice that bring together my research as an independent arts journalist and cultural and media studies researcher. With this aim, the article looks first at the changing global context of art journalism, then reflectively outlines a cultural theory informed by polyphonic musical form to analyse the writing of two case study articles on artists from the Asia Pacific region: Guo Jian from the post-Tiananmen Chinese artists diaspora; and Charlie Co from the Black Artists of Asia group in the Philippines (Skilbeck, 2001; 2003).

In its mediation and construction of the contemporary art world, art journalism constitutes a field of opposites and extremes. On the one hand, the context of the global changes that have impacted on and produced the social construction known as the 'international contemporary art world' has to an extent produced new modalities and forms of independent art journalism in art magazines. These not only reflect and articulate the innovation of contemporary art in the field of cultural production but also the increasingly cross-cultural transnational communication of the art world, mediated through independent art writing and journalism. On the other hand, mainstream mass media reporting - particularly in art world centres such as London, and global online reporting, for instance in London-based The Art Newspaper-on the rapid expansion of the largely unregulated economy of the art world — which in the mass media focuses on record-breaking auction prices - raises questions as to who is deciding the cultural, aesthetic and economic value of contemporary art and to what extent these values are 'pathologically' dissociated? Indicating the monetary and social scale of the art world 'billionaire boom', recent broken records include US\$72.8 million paid for a post-war Rothko abstract painting, consigned by David Rockefeller and bought by the Emir of Qatar at auction at Sotheby's New York, in May 2007 (Thornton \& Adam, 2008, p. 1). While I - very briefly_-sketch the 'global' context of art market coverage in the mainstream and online media, the research discussed here is primarily concerned with the opposite pole: the cultural production of contemporary art writing, and in particular changing aesthetic values and innovative modalities of art writing emerging through cross-cultural exchange between writers and artists, in the form of independent art journalism in visual culture magazines and journals. 
My approach to 'globalisation' is informed by Bourdieu's sociological field theory in relation to the economic field and the cultural field (2005, 2003, 1993). I adapt his concepts of the heteronomous and autonomous poles, cultural and economic capital, and symbolic power to differentiate the complex overlapping fields of the global contemporary art market (economic field) and the international contemporary art world (cultural field); and arts journalism. Bourdieu's $(2005 ; 2003)$ theory positions professional practice dominated by imperatives of economic capital at the heteronomous pole. The polar opposite is autonomy in which a producer is 'free' to create cultural products according to cultural and creative concerns. An example of the former in arts journalism might include writing influenced by sponsorship, advertising or public relations. An example of the latter is the autonomy of an independent writer and/or artist who is concerned purely with the creative processes of cultural production.

The article interweaves the following themes:

- I explore a methodological approach informed by music to interpret the complex interplay of cultural production in art journalism.

- In contrast, I will propose and test a polyphonic musical analogyas a paradigm of social communication in cultural production, and as a dialogic, pluralistic methodology for interpreting subliminal, autonomous language structures in writing about contemporary art in the mass media.

- These seek to account for the co-existence of individual subjectively constructed 'human' cultural responses articulated in the creative processes of art making and art journalism; through the 'inhuman' technological tools of production that literally manifest the modernisation processes of capitalism, and which are exemplified in the changing technologies of the heteronomous mass media.

- Through this approach, the paper identifies different tones and tonalities in writing about the global art market and local-or regional-cultural production, and reflects on new crosscultural modes and modalities arising in independent art writing at the autonomous pole of art journalism.

\section{Art journalism and the economic field}

Art journalism, the media, contemporary art, and globalisation together have 
created a dynamic contradictory dual-economy that reflects and enacts the excesses and values of contemporary global capitalist society at the end of the first decade of the 21 st century. The contradictions exemplified in the contemporary art world and art market are signified by the fundamental differentiation between fields of cultural and economic production. These can be characterised in terms of the different ways an art work may be seen-firstly by an artist or an art critic who is driven solely by creative concerns of artistic production; and secondly by an art investor, a gallerist, or an auctioneer who wants to make money from the art work. These different ways of seeing translate into the attribution of different kinds of valuesaesthetic, cultural and monetary - to works of art. The inherent irony of this process, reveals the valuation of art as an exemplar of the socially constructed 'game' (Bourdieu, 2008)) of economic and cultural value - a game in which cultural capital translates into economic capital — on the 'agreement' of a dominant social group (marshalled in the art world through the auction house), with the economic means to bestow monetary value on a certain 'shared' aesthetic taste which is the result of contextual background, environmental factors such as education and social upbringing - and which is also, incidentally, a way of maintaining, increasing, and transferring economic capital. The ultimate irony of this is that, as Bourdieu pointed out in his analysis of 'the production of belief', the art business is a trade in things 'that have no price' (Bourdieu, 1993, p. 74), that 'belongs to the class of practices in which the logic of the pre-capitalist economy lives on' (ibid). Such values are reproduced and reinforced — and less usually may be contested - through the niche and mainstream media.

Mediated through art writing and journalism, the expansion of the socially constructed field of 'the international contemporary art world' has been facilitated by the convergence of digital media, art journalism and the global economy which has seen the cultural field of contemporary art expand from its western, Eurocentric and transatlantic beginnings into a 'booming' global economy. Worth an estimated US\$20-30 billion annually-art is now the largest legal economy in the world to be almost unregulated (Haden-Guest, 2008). Among the most recent developments reported in the global art media is the increasing participation in the global contemporary art market by billionaire collectors, including royalty, from parts of the world new to the contemporary art map - the Middle East, Russia and China. Another much reported trend 
is the escalation in value of contemporary Chinese art and the entry of China into the international contemporary art world. Ironically, amongst those artists whose works are now commanding over a million dollars at auction in London and New York, many were part of the post-Tiananmen exodus of young artists; one time exiles, they are now able to move freely to and from their homeland, as China enters the global art world. Of the global art media, The Art Newspaper has most assiduously given close coverage to these developments, and the informative, investigative yet economically focused tone of this reportage is indicated in articles that report on global art market news. It has, for example, recently 'been able to reveal' the 'mystery buyers' of a number of recent record breaking auction sales, including: 'The Emir of Qatar and his wife', a billionaire 'Ukrainian collector', and a 'Georgian mining magnate' whose combined purchases of British and North American contemporary art have added hundreds of millions of US dollars to the art economy in the past year alone (Thornton \& Adam, 2008, p. 1).

Further recent developments related to the Asia-Pacific region reported extensively in global media publications (such as The Art Newspaper and the New York based magazine Art Asia Pacific, which has offices in 14 regional cities), include the ever increasing participation of the new economies of Asia in the international contemporary art world, demonstrated in the rising number of international biennales and art fairs in cities across Asia including Shanghai, Beijing, Singapore, Yokohama, Istanbul, Taipei and Hong Kongfurther indicating the global expansion of the art world and art journalism. Concurrent with this expansion has been a huge upsurge in cultural tourism around the world that intersects with a worldwide regeneration of art museums including contemporary art museums (Collins, Darcy, Jordan, Skilbeck et al, 2008). In this international context, art journalism is becoming increasingly significant as a means of transmitting cross-cultural information that not only informs but significantly contributes to the social construction in the public sphere of the 'international contemporary art world'. However, the very rapid pace of global change producing these movements, and changing cultural and aesthetic values around the world, brings significant issues to do with artistic reception, criticism and value that have scarcely begun to be analysed and interpreted in critical discourse.

Whereas media pundits may talk about impacts of 'the billionaire boom', 'the quality of the works' and the phenomena known as 'buying the price'- 
the conflation by neophyte collectors of monetary worth with aesthetic and cultural value (Thornton, 2008) - there has been scant analysis of wider issues such as how the auction system works, how art is awarded its symbolic power, and given cultural and monetary value. The site of such analysis to date tends to be in the media, particularly The Art Newspaper. But very little media and cultural analysis has yet been conducted into the global cultural, and cross-cultural, transformations effected over the last 10 years by the expansion of the international contemporary art world and the range of roles that art journalism has played in this.

\section{The cultural field}

Much of the recent writing about contemporary art has been through art writing and journalism in visual culture magazines, art journals, newspaper arts pages, and online media. A 'paucity in new critical writing' has recently been criticised by Terry Smith, Professor of Contemporary Art History and Theory at Pittsburgh University (and former director of Sydney's Power Institute). He writes in Contemporary Art and Philanthropy (2008) that since the 1960s and 1970s '[a]rt history departments - both within humanities faculties and associated with art schools-were less able to mentor the informed, independent and engaged criticism that contemporary art needs, leaving the field open to populist writing in the newspapers, which has longterm debilitating effects on local art scenes' (Smith, 2008, p. 15). While agreeing in some aspects with this point-particularly as it applies to the reduction of provision for mentorship of art criticism - there are notable exceptions to this strong claim. For example, in Sydney, John McDonald, art critic for The Sydney Morning Herald has consistently covered developments and events in Australian contemporary art for years, and is one of the few art critics to have given coverage to the changes in China in a mainstream newspaper (McDonald, 2007). Sebastian Smee, until recently national art critic for The Australian, has also been a strong voice in the Australian art world whose views are engaged and critical, following his own prescription according to which: '[g]ood criticism...should be risky, challenging, candid and vulnerable. It should be urbane one moment, gauchely heartfelt the next...' (Smee, 2008). Such newspaper criticism develops rather than diminishes art scenes; and more, not less, of such criticism is needed. Yet I suggest that the portents are not unfavourable for criticism. A transition 
has been occurring in critical writing. During this time, the context of the global changes which have produced the contemporary art world have also to an extent begun to produce new intercultural modalities and forms of independent art writing and art journalism that are in themselves innovative and creative - and reflect and articulate the innovation of contemporary art in the field of cultural production.

\section{A renewable cultural and aesthetic approach}

Changes in the contemporary art world and art journalism call for a range of new media and culture theories to address and interpret these ongoing global changes. Before discussing the case study stories, I outline a methodology that I was researching at the time of writing the stories. My purpose in discussing this conceptual approach is to begin to apply a latent interpretation informed by poststructuralist and psychoanalytic theory, and the semiotic meanings of musical form, to the cultural production of meaning in the writing of art journalism. The significance of using musical analogies in cultural criticism and social theory is that music constitutes an expression of social relations, whether in actual or transcendental (ideal) form. Music furthermore articulates language on an unconscious, affective semiotic level that goes beyond linguistic structures yet resonates with both visual perception and verbal articulation.

Numerous cultural critics, including Adorno (1976) and Weber (1958) have suggested that modern harmonic chordal western music symbolically represents Western capitalism. In counterpoise, I suggest that the conceptual structures, techniques and modality of the pre-modern musical fugue form have an analogous relevance for interpreting subliminal, unconscious and autonomous aspects of interpersonal social communication that may have been overtly suppressed through industrialised technological modernity (Kristeva, 1982). Yet these aspects may still be found inscribed and articulated through the mass media of modernity (Kristeva, 1982) and digitised mass media of 'post-modernity' - in forms of independent arts journalism.

The musical fugue (derived from the Latin fuga for flight) is a self-referential reflexive melody-based form that produces potentially infinite variations on a theme through the interweaving of 'voices' (instruments) using techniques of polyphony and counterpoint. The modality of the fugue form is one of possibility, coming into being, contingency, change - and also cause 
and effect. As it is based on an individual interpretation of a given theme, it is a particularly apt model for art journalism and aesthetic criticism which responds to an artistic text or texts. As the fugue is composed of individual voices melodically playing interpretations of a theme it is also a model of democratic pluralism and cultural diversity (Bakhtin, 1981).

Objections may be raised to the analogous use of fugue that I propose on the grounds that the fugue at its apex in the Baroque era was not practised by a representative sample of people, and was dominated by a male composer, Bach. Yet the origins of the fugue belie its later artistic refinement. These origins are in the singing voice in the form of the round. It is indeed one of the earliest social forms of music - originating as an improvisatory melodic form based on practice not text; it thereby has an analogous application to interview-based feature writing where the written text originates in the spoken voices in conversation. As a democratic form of singing it is epitomised in communal songs, the nursery rhyme Three Blind Mice-is an example of a round in which all people in a household or a community could join in. Such early forms of polyphonic music were widely practised by women, children, and people of all ages. When feminist critics, Kristeva and Cixous, sought to find psychoanalytical origins of expressive innovative writing they each returned to the early music of the singing voice - Kristeva in concepts of semiosis that she applied to literary writing and Cixous in the underlying musical rhythms of écriture feminine. In a similar mode, I suggest that the latency of this democratic polyphonic form in social communication and cultural production gives the fugue form relevance as a heuristic vehicle for investigating autonomous modalities of writing in the form of art journalism in the mass media. In reflecting on the case studies I will test the significance of fugue as a cultural paradigm, and modality of writing, in two interview-based, visual culture magazine stories that introduce new artists and their innovative works, in a social and cultural context.

As the fugue is a pre-modern, pre-capitalist form, and the art business is based on a pre-modern, pre-capitalist practice (Bourdieu, 1993), there is a further symbiotic logic to using the fugue structures as a methodology for interpreting the communication and media structures of the art world, particularly as mediated through independent art journalism.

This is the polar opposite of 'art journalism' as public relations - a promotional economically motivated practice of commodification, which is at the heteronomous pole of cultural production. 
The fugue's meanings are linked by the suggestion of 'flight'. I suggest that the fugue's meaning as the psychogenic fugue, a temporary state of amnesia and a wandering journey preceded by traumatic experience, also has an analogous application to the creative processes of art making and writing in modernity; and I will consider how this psychogenic meaning resonates throughout the artists' storytelling mediated through the writing of the 'case' stories.

\section{Methodology: Fuguism}

In this context, I discuss ways that the methodology of dialogism (polyphony) exemplified by the fugue form can be used as a philosophical and practical methodology for interviewing, and presenting the information in a story, and as a wider theoretical frame for aesthetic analysis, as well as interpretation of social and cultural communication.

\section{Artists telling stories}

Two feature stories serve as case studies to illustrate selected themes of polyphony and cross-cultural fugal modalities of story telling in art writing, drawn from my own experience and interpretation.

The stories are interview-based features: on the Australian-Chinese artist, Guo Jian, and his satirical political pop art, entitled 'From Mao to Now', published in black + white in 2001. And on the work of Charlie Co, an artist from Negros in the Philippines, in a story entitled 'Charlie Co: Visionary Artist' published in POL Oxygen: Design, Art, Architecture in 2003.

The feature stories, separately, tell the stories of the cultural journeys of two Asian-born contemporary artists whose works create intercultural visual languages mixing 'eastern' and 'western', northern and southern styles of representation drawn from and transforming the traumatic life experiences of the artists (Skilbeck, 2000; 2003).

Methodologies used in the articles include long, face-to-face, interviews with each artist, background interviews with the director of the gallery in Sydney's Surrey Hills, where they were represented, online research, art library research, and further background interviews with art workers at the gallery and artists who are part of the regional art scenes. Crucially, the research for each story involved being shown around their exhibition by the artist who gave a detailed commentary on their works. What they talked about 
included: the content, form and style of the artworks - what they were inspired by, the creative processes involved, the social and cultural contexts in which they were created, the meaning of particular imagery, motifs and icons. Each artist created works that demonstrated in innovative ways the practice of cultural hybridity, the mixing of motifs, images, icons, symbols from the cultural traditions of their homeland and European or American art traditions: in Guo Jian's case social realism mixed with political pop art; for Charlie Co, Filipino imagery mixed with surrealism. The artists told me their stories of their artworks.

I transcribed these dialogues and later wove some of these anecdotes, fugally, into the text of the written feature stories. Here I deconstruct, and reconstruct, the conversational interweaving of the story text.

\section{Guo Jian's nightmares}

Art from the Third Space dreams in both East and West. It is art with a unique perspective, defined by the experience of exile and cultural dislocation coupled with increasing freedom of expression (in China [at the time the story was written] political and erotic themes remain banned). (Skilbeck, 2001, p. 24)

Guo Jian arrived in Australia as a selfexiled refugee in 1992 following the events of 1989 in Beijing.

In interview, Guo Jian recounted the nightmares which still haunted him of the events in 1989, when he was an art student, which form the subject material of the paintings in his first solo exhibition, Trigger Happy. Before studying for his BA in Chinese Painting and Literature at the China central minorities Institute in Beijing, Guo Jian had been a soldier in the Red Army. He was haunted by the shock of his realisation that, as he put it, he could have been firing at himself. Hence all the soldiers he depicts in his artworks have his face, often masked by an oversized fixed

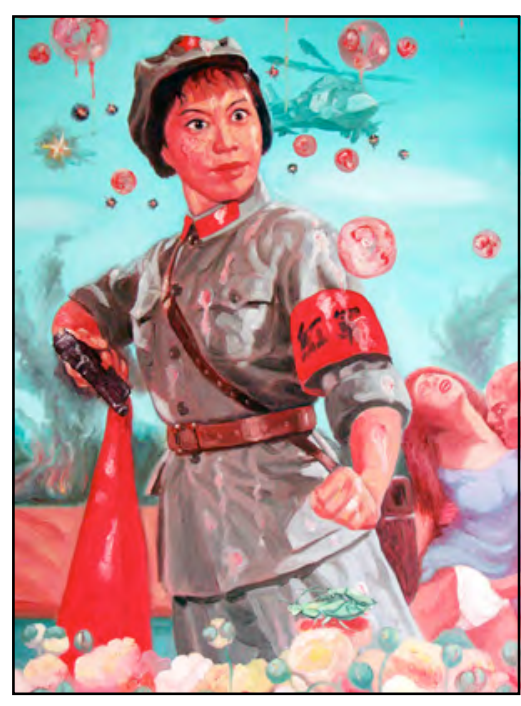

Figure 1: Gua Jian's paintings transformed his underlying trauma. 
grin. His paintings transform the savage underlying trauma of his experience of flight, exile and survival into a riotous satire. The story continues, with my interpretation of the artist's work:

Most tellingly, Guo Jian's work demonstrates the impact between the sexuality of communist China-sexuality repressed and channelled into militarism - and the liberal West. For instance Trigger Happy III portrays ballet dancers, dressed as rifle-toting girl soldiers in the pre-communist uniform of shorts, sailing through the air while in front of them, bare-chested Guo Jian's point phallic red toy guns. (ibid., p. 25)

The article then quotes Guo Jian, interweaving his voice into the hybrid structure of the story:

'In China after the start of communism women were not allowed to wear shorts,' explains Guo Jian. 'In the 70s the Revolution Ballet toured all over China, depicting aspects of revolutionary life. The Red Women's Detachment ballet was about pre-communist women soldiers. This was the ballet that everyone flocked to see. Men loved to go to the ballet to see the women of the Red Detachment in shorts. I paint myself doing the same ballet, in a soldier's pose, an attack pose. I learnt that in the army, I was part of the ballet'. (ibid., p. 25)

By interweaving Guo Jian's voice into the story, the writing enacts a cosmopolitan dialogism that contains elements of cultural hybridity.

The use of quite extensive quotation allows the voice of the artist to be heard telling his own story. The artist's voice is, furthermore, effectively heard in the images of his works that accompany the text of the story. The visual images constitute a significant part of the narrative. The reader may enter the text through the images and interpret these according to their own cultural background. The writing conveys an intercultural story in a modality of dialogism composed of the writer's voice, the artist's quoted voice and the 'voice' of the artworks.

You go to the army; you become a hero so you can get a girlfriend. You don't really care about going to war, killing people. People think that it's really beautiful to join the army. (ibid., 26) 
The writer picks up the story and fills in for the reader:

... But the thought troubles him deeply that, had he not left the army, he could have been carrying out the killings.

Now the artist's voice comes in, like a voice in a fugue, or a conversation, developing the theme:

Once in 1991, I met a soldier in a hospital. He was a soldier in the [...] massacre. He told me about how he killed people there. He got excited. I said that it's not good to kill people. But he never felt regret about that. He never [thought] about that, that it's a really bad thing to kill people. That made me think about how people get excited by violence. (ibid., p. 26).

The story ends with a summary of the 'message' or 'address' of the artist's work in the writer's (my) interpretation. It is an anti-violence message.

The text is a generic hybrid, mixing codes and conventions of the genres of artist profile and critical review, thus performatively, and semiotically, illustrating cultural hybridity in its form as well as content. The uses of typography, colour and design all mix codes in the cross-cultural modality of the story telling. References to carnivalesque elements in the artist's work are - playfully - represented visually in the graphic design and layout of the story. The layout is ironic, overturning the conventions of traditional print media. The columns are slanted; there is a bold use of the colour pink.

As the story is told through a hybridisation of cross-genre visual, graphic and conceptual modes the reader may gain meaning not only from the content of the writing of the images but experientially from the overall presentation of the story. Significantly it is listed in the index under the section heading SAS - Short Attention Span. The story is 'ironically' designed and coded for the post-modern short attention span of the contemporary consumer, a new form of cultural tourist, an ironist with not much time who may enjoy a casual cultural experience, and catch the humour of the free play.

The art-photography journal was printed off shore in Malaysia, reflecting further impacts of globalisation on the technological production of media publications. 


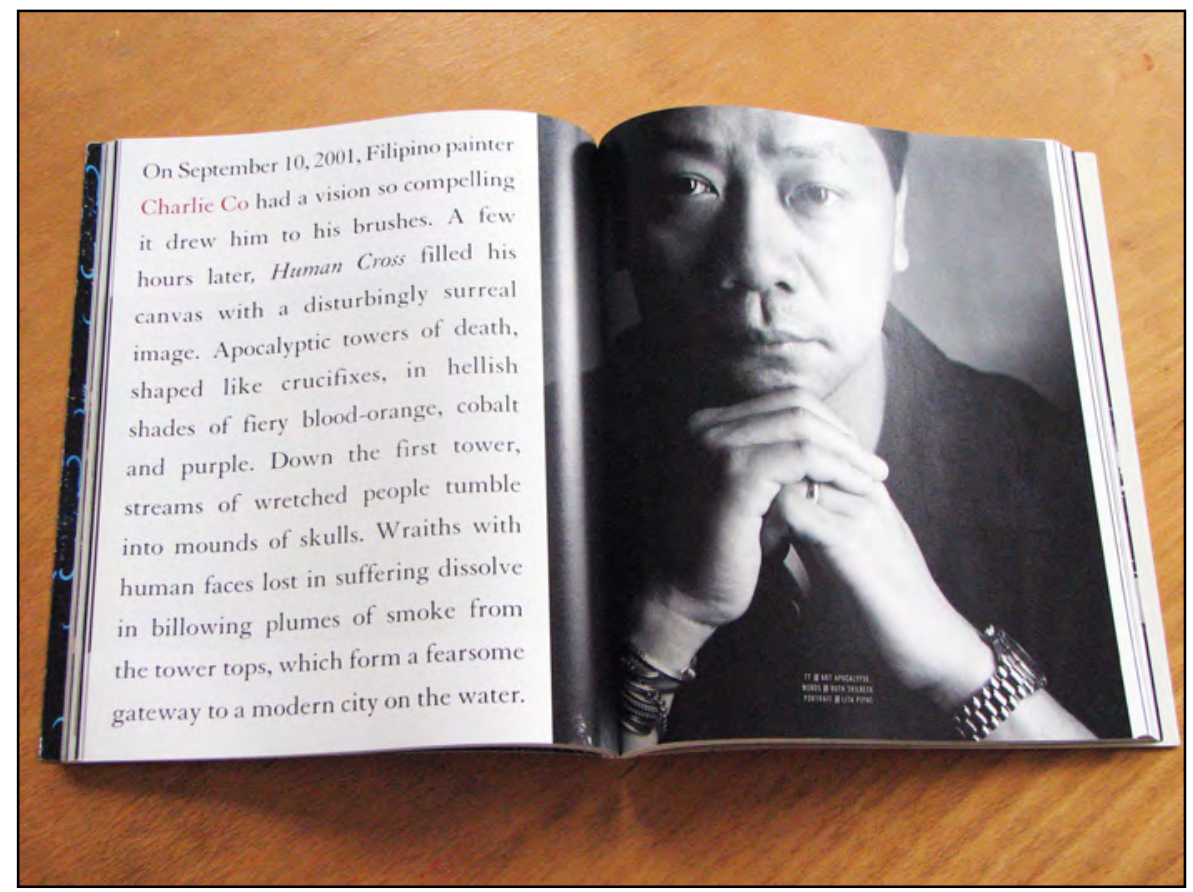

Figure 2: Charlie Co declaims 'the evils of corruption'.

\section{Charlie Co's dreams}

Charlie Co is part of a group of socially aware artists, the Black Artists of Asia (BAA) who are committed to resisting the pressure to move to Manila and instead develop an authentic art that represents and enacts the culture, history, and social and political concerns of their region. His work is particularly concerned with declaiming 'the evils of corruption' and in promoting social justice and peace through critiquing corruption and violence — and he is a storyteller. He told me:

I tend to always tell works which tell stories. My work is always a stage. To me life is a stage. There are always stories to tell. It may be happiness, tragedy, it may be dreaming. This is the way I work that balances me now. If one sees darkness, one shall see lightness, so one can balance oneself. I'm quite conscious of that state. When I approach a painting I don't like to be too conscious, too much intellectualising it. I prefer to say it from the heart as honestly as I can. (Skilbeck, 2003, p. 84) 
Charlie Co's works abound with local motifs and imagery which reflect the colonial past and conflicts of the present rural economy of Negros, including sugarcane fields, carozza (Catholic carriages still used in religious processions), references to Moro (Muslim heritage in the southern Philippines), bleeding hearts and crows - his symbol of corruption.

The article begins by describing one of Charlie Co's works-a vision that he painted on the eve of 11 September 2002. The editor of the magazine requested that I not name the attack on the twin towers, indicating the controversial and sensitive nature of the topic in the media. The story includes extensive quotes by $\mathrm{Co}$ in which he tells of how he paints from his dreams and visions, producing powerful apocalyptic dream works. The story concludes with his message committed to peace:

In this unstable time, we as artists cannot avoid creating works like this. He adds, [m]aybe in the future, we will see these works as a record of the times we're in. It's scary, but we still need to have the hope, the faith, the heart. As long as there's people fighting for peace in this world, there's hope. I never stop dreaming of this. (ibid., p. 83)

The story layout is innovative, in that the first page contains a written description of an artwork in very large type so that the words seem to occupy the page in concrete form reminiscent of a text by a language poet. Otherwise the story fits the format of the magazine, pages of text interspersed with pages of images of the artist.

A further, unconscious meaning of 'art writing' emerges in this crosscultural, cross-genre modality and that is the semiotic visual 'writing' of the artwork itself, which inscribes meanings to the viewer, interpreted according to individual cultural and psychological perception. The viewer completes the artwork and the written text.

\section{Reflection on new modalities of art writing}

On reflection on the habitus from which I wrote these stories, concepts I developed in the literary and cultural theory of fugue or fuguism-such as the fugal modality of writing, and the textual fugue-influenced the writing of the stories. This applies in terms of how I interpreted the cultural hybridity of the art works, my interpretation of the impact of trauma that both artists experienced in their lives, how this was transformed in their art works; 
and in my dialogic approach to writing the stories which was informed by techniques of polyphony, interweaving and counterpoint (Skilbeck, 2007). I was also reflexively influenced by my concurrent journalistic research into the transformation of art criticism, which I discussed in 'The Critic', one of a feature series I wrote on contemporary art in Australia, published in Australian Art Collector in 2003. The shift in focus - from 'traditional' art criticism based on aesthetic categories and a European canon is signified in the morphing of the term art critic into art writer - or at least in the addition of art writer to the terminology.

This term speaks for the capacity, willingness and ability to engage creatively with a work (rather than stark 'critical detachment'). There are lots of different ways to write about art. And there are many genres of art writing besides straight critical reviews that can involve critique and insight. (Skilbeck 2007, p. 88)

\section{Creating new meanings}

From the intersection of my cultural and journalistic media research I can conclude that, whereas traditional art criticism focused on explaining the 'unitary' meaning of canonical works of art, dialogic modalities of contemporary art writing in arts journalism, by virtue of being cross-cultural or intercultural, do not do that. This modality of art writing and aesthetic reflection moves beyond the canon of the cultures from which the dislocated writer and subject/artist may originally have come. Figuratively speaking, they meet in a zone which is de-territorialised and alive with creative potential, reminiscent of Kristeva's concept of 'the semiotic chora, which modifies linguistic structure' (Kristeva, 1986, p. 122). Yet this is a shared, externalised zone in the public sphere, created visually through the mediated material text of the exhibited artwork and re-mediated through the writing of the journalistic text. It is a zone in which new meanings are created-by those who enter through the sensory experiences of looking, reading and interpreting, the words and images of the texts, mediated through art journalism.

\section{Art journalism: social change, entropy and innovation}

In writing these stories, I experienced a challenge that art writers may wish for, and never find: an encounter with highly significant, innovative, entropic, artworks. How to write about these? How to write about art 
that is on the cutting edge of intercultural experience and expression? Contemporaryartthatcreates hybrid products sonew they havenotbeennamed? Social and cultural formations one has never before experienced? This raises issues that extend beyond professional journalistic practice into cultural theory (Williams, 1981). As the case studies show, the authentic art that emerges in response to social upheavals and cultural dislocation, before art movements have been retrospectively defined, breaks existing conventions and is entropic, appearing as riotous outbursts of chaotic creativity, or creative chaos - it flowers before time moves on, the moment passes, the artist is, or is not, critically acclaimed and the artwork commodified, or not, by commercial interests of the art world.

In my experience, fugue techniques - dialogism, polyphony and counterpoint — can be used to develop innovative stories that seek to authentically represent the artist and their works within social and cultural contexts, and that in their writing create something new at the same time.

\section{Significances of fugue modalities in art journalism}

The experience of writing these stories demonstrated that cross-cultural modalities of participatory story telling in independent art journalism can transcend and transform the racial and cultural divisions of cultural imperialism, the legacy of colonialism, producing new forms of cultural production. The level of conviction in such modalities is contingent on an exchange of free expression, in an egalitarian democratic encounter. High levels of conviction, without seeking to be ideologically persuasive, occur in art writing that is the product of authentic cross-cultural communication that occurs betweenacuriousand sympatheticjournalist, andanartistwhoseartworks articulate a profound creative response to social and cultural conditions of the artist's life. Independent art journalism allows the opportunity for artists, and art journalists, to bear witness in words as well as images. Thus, autonomous contemporary art reporting may provide authentic insight into situations and events, including conflicts, wars and social change that may be glossed or ignored by mainstream media.

While independent art journalism may provide a necessary culturally oriented counter-balance to the economic focus of the mainstream media art reporting, there are further issues pertaining to the cultural and economic fields that impact upon the practice of independent art journalists. These demonstrate 
the marginal nature of the independent cultural practitioner in a competitive field of symbolic power. Freelance art journalists may find it difficult to place their work and when they do they may be given low status recognition-it has been common in some Australian visual culture and design magazines for the journalist's byline to be rendered in type face so small it is barely legible. There are also issues to do with the content of the story that arise when the text is so mediated by a designer that its visual impact overrides the content of the writing. Another point is that the content of a story may be given a new meaning according to the surrounding advertising and its placement in the publication - all of which is beyond the control of the independent art writer. There is little opportunity for engaged, indepth critical analysis of art in the mainstream, and even in the independent media, and the publications that commission freelance journalists may offer constrained forums of writing - often due to extraneous interests. As contemporary art is by virtue of its contemporanity a field of continuous change, most of its discussion and analysis take place of necessity in the media in the public sphere. Yet lack of opportunities for independent informed analysis in and of art journalism has impeded critical and cultural discourse at the same time that the global art economy has overheated, dominated by global economic capital and abetted by some forms of mainstream mass media art market reporting.

\section{Coda}

Given the increasing size and economic value of the art world, contemporary art is becoming an increasingly significant field of both economic exchange and cultural communication-literally embodying changing symbolic values in the global public sphere. The symbolic cultural exchange of contemporary art, mediated through art journalism, has the potential to powerfully benefit the global public and the ideal of 'cosmopolitan civil society'. But the wider cultural and social value of international arts journalism and art criticism has been largely overlooked in critical discourse over the past two to three decades (Smith, 2007). This has placed the onus on individual independent art writers and journalists with a compatible habitus to follow their intuition in writing about contemporary visual art_often against a prevailing orthodoxy which has marginalised arts journalism as research. Yet the context of 'globalisation' and the rapid expansion of the art world is changing aesthetic and cultural values and bringing to the fore questions about 'a new global 
aesthetic', and the role of art in cross-cultural communication and exchange, including the excessive commodification of art in global consumer societies. These ongoing changes suggest future directions for journalistic and cultural research into how societies value art, what drives the cultural, economic and social dynamics of the field of the international contemporary art world; and the cultural and economic significances of how the art world is constructed and mediated through various forms of art journalism in the mainstream and specialist art media.

\section{References}

ABC News. (2007, October 13). Tiananmen Square painting smashes Chinese art record sale. Retrieved on 6 January 2008, from: www.abc.net.au/new/stories/2007/10/13

Adam, G. (2007a). Chinese buyers thin on the ground at first Shanghai art fair.

The Art Newspaper, pp. 1-4. Retrieved on 22 December 2007, from: www.theartnewspaper.com/article.

Adorno, T. W. (1976). Introduction to the sociology of music. Trans. E.B.Ashton. New York: The Seabury Press.

Anderson, B. (1991). Imagined communities: Reflections of the origin and spread of nationalism. London: Verso.

Bacon, W. (2006). Journalism as research? Australian Journalism Review, 28(2): pp. 147-157.

Bakhtin, M. (1981). The dialogic imagination: Four essays. Michael Holquist (Ed.) Trans. Carl Emerson and Michael Holquist. Austin and London: University of Texas Press.

Baudrillard, J. (1985). The ecstasy of communication. In H. Foster (Ed.)., Postmodern culture. London: Pluto.

Bauman, Z. (1992). Intimations of postmodernity. Oxon: Routledge.

BBC News (2008, February 8). Auction 'sets modern art record. Retrieved on 2 October 2008, from: www.newsvote.bbc.co.uk/mpapps/pagetools/print/news. bbc.co.uk

Bhabha, K. H. (1994). The location of culture. Oxon: Routledge.

Bourdieu, P. (2003). Firing back: Against the tyranny of the market 2. London: Verso.

Bourdieu, P. (2008/1993). The field of cultural production: Essays on art and literature. New York: Columbia University Press.

Bourdieu, P. (2005). The political field, the social science field, and the journalistic field. In R. Benson and E. Neveu (Eds.)., Bourdieu and the journalistic field. Cambridge: Polity Press

Collins, J.; Darcy, S.; Jordan, K.; Skilbeck, R.; Peel, V.; Dunstan, D.; Lacey, G.; Firth, T. (2007). Cultural landscapes of tourism in New South Wales and Victoria. 
A final report to the Sustainable Tourism CRC. 150 pp. Publication pending. www. cretourism.com.au.

Connell, R. (2007). Southern theory: The global dynamics of knowledge in social science. Sydney: Allen and Unwin.

Cottle, S. (Ed.). (2003a). Media organisations and production. London: Sage.

Cottle, S. (Ed.). (2003b). News, public relations and power. London: Sage.

Deleuze, G. and Guattari, F. (1980). Milles plateaux, Vol 2 aux Capitalism et schizophrénie. Paris: Les Editions de Minuit.

Dunn, A. (2004). Ways the media matter: Three accounts. Continuum: Journal of Media and Cultural Studies. 18(3): pp. 459-4.

Foster, H. (Ed.). (1983). Postmodern culture. London: Pluto.

Gillen, P. and Ghosh, D. (2007). Colonialism and modernity. Sydney: University of New South Wales Press Ltd.

Habermas, J. (1983). Modernity—an incomplete project. In H. Foster (Ed.)., Postmodern culture. London: Pluto.

Innis, H. (1952). Changing concepts of time. Toronto: University of Toronto Press.

Jameson, F. (2003). Postmodernism or, the cultural logic of late capitalism. Durham: Duke University Press.

Krauss, R. (1983). Sculpture in the expanded field. In Postmodern culture. In H. Foster (Ed.)., Postmodern culture. London: Pluto.

Kristeva, J. (1982). Powers of horror: An essay on abjection. Trans. Leon S. Roudiez. New York: Columbia UP.

Kristeva, J. (1986). The Kristeva reader. Trans., ed. and intro. Toril Moi. Oxford: Blackwell.

Maerkle, A. (2007). Shcontemporary serves up Asian match point. ArtAsiaPacific. No. 56. Nov/Dec: p. 86.

McDonald, J. (2007, November 10-11). From under the red cloud. Sydney Morning Herald, pp. 16-17.

McLuhan, M. (1962). The Gutenberg galaxy: The making of typographic man. Toronto: University of Toronto Press.

Media, Entertainment and Arts Alliance. Retrieved on 9 October 2007, from: www.alliance.org.au

Mumford, L. (1952). Art and technics. New York: Columbia University Press.

National Union of Journalists. Retrieved on 22 December 2007, from: www.nuj.org.uk

Ng, Elaine, W. (2007). Editorial:Horizontal collaboration. ArtAsiaPacific No. 55 Sept/Oct: p. 8

O'Shaugnesey, M. and Stadler, J. (2006). Media and society, an introduction. Third edition. Oxford: Oxford University Press.

Ruiz, C. (2007). China gets its first contemporary art museum. The Art Newspaper. Retrieved on 22 December 2007, from: www.theartnewspaper.com/article.asp 704

Sanders, K. (2003). Ethics and journalism. London: Sage. 
Said, E. (1983). Culture and imperialism. New York: Vintage

Schiller, H. (1976). Communication and cultural domination. White Plains, New York: International Arts and Sciences Press Inc.

Shcontemporary Art Fair (2008). Retrieved on 15 February 2008, from: www.shcontemporary.info

Skilbeck, R. (2007a). The writer's fugue: Musicalization, trauma and subjectivity in the literature of modernity. Unpublished $\mathrm{PhD}$ thesis. University of Technology, Sydney.

Skilbeck, R. (2007b). Tourism and/or cosmopolitanism: Art museums as contested sites of cross-cultural regeneration for civil societies. UTS Conference on Cosmopolitan Civil Societies. University of Technology, Sydney. Oct 23-24 2007. Publication pending.

Skilbeck, R. (2007c) The new philanthropy. Australian Art Collector. Issue 42 July- Sept.: pp. 104-105.

Skilbeck, R. (2007d). The new philanthropy 2. Australian Art Collector. Issue 42 July-Sept.: pp. 105-106.

Skilbeck, R. (2007e). Changing cultural landscapes. U Magazine. Sydney: University of Technology, Sydney. www.newsroom.uts.edu.au/opinion/detail.

Skilbeck, R. (2003). Visionary painter/Charlie Co. POL Oxygen: Design, Art, Architecture. Issue 3. Sydney, Australia: pp. 76-83

Skilbeck, R. (2003). Australian Contemporary Art Comes of Age : 'The artist'; 'The gallerist'; 'The curator'; 'The critic'. (4 feature series). Australian Art Collector. Issue 25 July-Sept. Sydney, Australia: pp. 75-89.

Skilbeck, R. (2000). From Mao to now. black + white. Issue 42. Sydney, Australia: pp. $24-26$

Smee, S. (2008). The mind of a critic. The Australian. Retrieved on 30 April 2008, from: www.theaustralian.news.com.au/story

Smith, T. (Ed). (2008). Contemporary Art + Philanthropy. Sydney: University of New South Wales Press.

Sztompka, P. (2004). The trauma of social change: A case of postcommunist societies. In Cultural Trauma and Collective Identity. Berkeley, California: University of California Press.

Thornton, S. (2008) The recipe for a record price: auction house hype, media frenzy, and billionaire buyers. The Art Newspaper. Retrieved on 1 May 2008, from: www.theartnewspaper.com/article.asp 704. Published 1/05/08.

Thornton, S. and Adam, G. (2008, May 4). Revealed: \$72.8m Rockerfeller Rothko has gone to Qatar. The Art Newspaper. Retrieved on 4 May 2008, from: www.theartnewspaper.com/article.asp 704

Weber, M. (1958). The rational and social foundations of music. Trans. Don Martindale. Carbondale: Southern Illinois University Press.

Weber, I. and Jia, . (2007). Internet and self-regulation in China: the cultural logic of controlled commodification. Media, Culture and Society. 29(5): pp. 772-789. 
Williams, R. (1958). Culture. London: Chatto and Windus.

Zelizer, B. (2008). Why memory's work on journalism does not reflect journalism's work on memory. Memory Studies, 1(1): pp. 79-87.

Dr Ruth Skilbeck is a writer and photographer with a background in international contemporary art journalism. She holds a BA (Hons) from the University of London, an MA in writing and a PhD on The Writers Fugue (critical and cultural theory). Over the past four years she has researched and lectured in the Department of Journalism and Social Inquiry at the University of Technology, Sydney. Her current research interests include contemporary art writing, journalism and globalisation; trauma, art and journalism; exiled writers, human rights and media policy; innovation and experiment in new media art and writing.

Ruth.Skilbeck@uts.edu.au

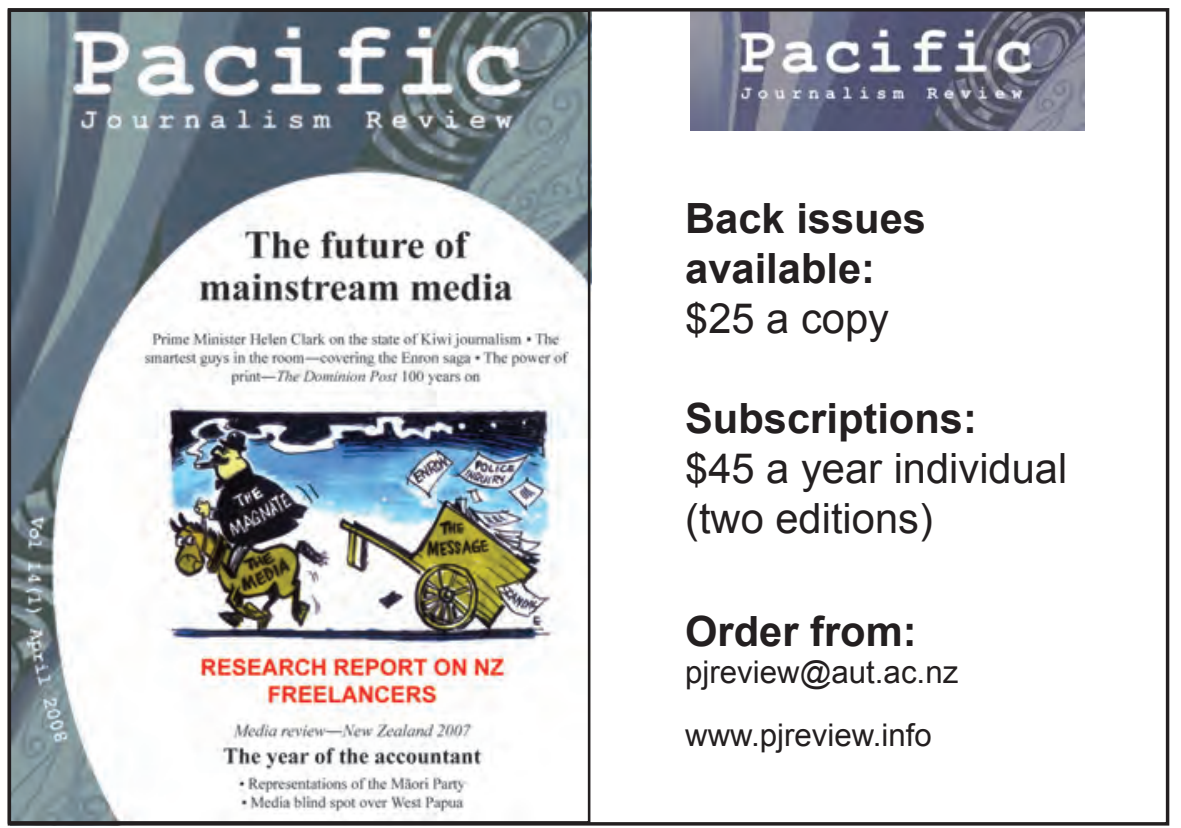

